University of Nebraska - Lincoln

DigitalCommons@University of Nebraska - Lincoln

2004

\title{
Methodology for Estimating Removable Quantities of Agricultural Residues for Bioenergy and Bioproduct Use
}

\author{
Richard Nelson \\ Kansas State University, 133 Ward Hall, Manhattan, KS \\ Marie Walsh \\ Oak Ridge National Laboratory, Oak Ridge, TN \\ John Sheehan \\ National Renewable Energy Laboratory \\ Robin Graham \\ Oak Ridge National Laboratory, Oak Ridge, TN
}

Follow this and additional works at: https://digitalcommons.unl.edu/usdoepub

Part of the Bioresource and Agricultural Engineering Commons

Nelson, Richard; Walsh, Marie; Sheehan, John; and Graham, Robin, "Methodology for Estimating Removable Quantities of Agricultural Residues for Bioenergy and Bioproduct Use" (2004). US Department of Energy Publications. 9.

https://digitalcommons.unl.edu/usdoepub/9

This Article is brought to you for free and open access by the U.S. Department of Energy at DigitalCommons@University of Nebraska - Lincoln. It has been accepted for inclusion in US Department of Energy Publications by an authorized administrator of DigitalCommons@University of Nebraska - Lincoln. 


\title{
Methodology for Estimating Removable Quantities of Agricultural Residues for Bioenergy and Bioproduct Use
}

\author{
Richard G. Nelson, ${ }^{*}, 1$ Marie Walsh, ${ }^{3}$ John J. Sheehan, ${ }^{2}$ \\ and Robin Graham ${ }^{3}$ \\ ${ }^{1}$ Kansas State University, 133 Ward Hall, \\ Manhattan, KS 66506, E-mail: rnelson@ksu.edu; \\ ${ }^{2}$ National Renewable Energy Laboratory, \\ 1617 Cole Boulevard, Golden, CO 80401; and \\ ${ }^{3}$ Oak Ridge National Laboratory, Oak Ridge, TN 37831-6194
}

\begin{abstract}
A methodology was developed to estimate quantities of crop residues that can be removed while maintaining rain or wind erosion at less than or equal to the tolerable soil-loss level. Six corn and wheat rotations in the 10 largest corn-producing states were analyzed. Residue removal rates for each rotation were evaluated for conventional, mulch/reduced, and no-till field operations. The analyses indicated that potential removable maximum quantities range from nearly 5.5 million dry metric $t / y r$ for a continuous corn rotation using conventional till in Kansas to more than 97 million dry metric $\mathrm{t} / \mathrm{yr}$ for a corn-wheat rotation using no-till in Illinois.
\end{abstract}

Index Entries: Corn stover; wheat straw; rainfall erosion; wind erosion; tolerable soil loss.

\section{Introduction}

Current US primary energy consumption is about 102 exajoules (EJ) (97 Quads) and is expected to increase to >137 EJ (130 Quads) by 2020. Transportation fuels produced from oil are projected to account for nearly one-third of the projected energy use by 2020 , with nearly $68 \%$ of the oil imported from unstable and/or unfriendly countries, resulting in a trade imbalance of more than $\$ 206$ billion (US \$ in \$2001). Additionally, the use of fossil fuels for transportation and electricity is a significant contributor of greenhouse gasses such as carbon dioxide, nitrogen oxides, and carbon monoxide (1-4).

*Author to whom all correspondence and reprint requests should be addressed. 
Table 1

Total Production, Residue Generation, and Gross Energy Amounts for Three Major Commodity Crops in the United States ${ }^{a}$

\begin{tabular}{lrrrrrr}
\hline Crop & & & & & & Average for \\
Corn & 1997 & 1998 & 1999 & 2000 & 2001 & $1997-2001$ \\
$\quad$ Production (billion bu) & 9.20 & 9.75 & 9.43 & 9.91 & 9.50 & 9.56 \\
$\quad$ Residue (million dry Mg) & 234.30 & 248.40 & 240.00 & 252.30 & 241.90 & 243.40 \\
$\quad$ EJ & 3.50 & 3.70 & 3.60 & 3.80 & 3.60 & 3.60 \\
Winter Wheat & & & & & & \\
$\quad$ Production (billion bu) & 1.84 & 1.88 & 1.69 & 1.56 & 1.30 & 1.65 \\
$\quad$ Residue (million dry Mg) & 85.50 & 87.10 & 78.60 & 72.60 & 63.10 & 77.30 \\
EJ & 1.30 & 1.30 & 1.20 & 1.10 & 0.90 & 1.10 \\
Spring Wheat & & & & & & \\
$\quad$ Production (billion bu) & 0.54 & 0.52 & 0.50 & 0.55 & 0.51 & 0.52 \\
$\quad$ Residue (million dry Mg) & 19.40 & 18.70 & 17.80 & 19.70 & 18.10 & 18.70 \\
EJ & 0.30 & 0.30 & 0.30 & 0.30 & 0.30 & 0.30 \\
\hline
\end{tabular}

${ }^{a}$ Production (billion bu), gross residue levels (million metric dry t), and energy (EJ).

An important component of becoming less dependent on fossil-based resources is to produce bioenergy and bioproducts from renewable energy resources such as biomass. Domestically produced bioenergy and bioproducts have lower environmental impacts, have a higher energy-profit ratio (ratio of renewable energy output to total energy inputs) than traditional fossil fuel technologies, and provide for economic development and enhanced energy security.

Among potential biomass resources that can be used to produce bioenergy and bioproducts are agricultural residues such as corn stover and wheat straw. Corn, soybeans, and wheat are the three largest crops produced in the United States, in terms of both acres and total production. Total production (billion bushels), residue quantities (million dry $\mathrm{Mg}$ ), and energy density (EJ) produced from corn for grain and spring and winter wheat for the period of 1997-2001 are presented in Table 1.

While residue quantities produced are substantial, only a percentage of them can be collected for bioenergy and bioproduct use. Agricultural residues play an important role in controlling erosion and maintaining soil carbon, nutrients, and soil tilth. Removal of agricultural residues for bioenergy and bioproduct use will require consideration of the quantities that must be left to maintain soil quality. A recent analysis has demonstrated that under appropriate conditions, removal of agricultural residue can potentially occur (5).

\section{Methodology}

Removal of agricultural residues for bioenergy and bioproduct use is directly influenced by a number of factors including grain yield, crop rota- 
tion, field-management practices within a rotation (e.g., tillage), climate, and physical characteristics of the soil such as erodibility and topology.

The goal of the analysis is to develop and apply a methodology to estimate quantities of agricultural crop residues that can be removed for bioenergy and bioproduct use from both continuous crop and multi-crop rotations, while maintaining rain and/or wind erosion rates $(\mathrm{Mg} /[\mathrm{ha} \cdot \mathrm{yr}])$ at or below the tolerable soil-loss level, $T$. $T$ is the maximum rate of soil erosion that will not lead to prolonged soil deterioration and/or loss of productivity as defined by the United States Department of Agriculture's Natural Resource Conservation Service (USDA-NRCS). For the purpose of this article, the methodology developed is applied to the top 10 corn-producing states (Iowa, Illinois, Indiana, Kansas, Minnesota, Missouri, Nebraska, Ohio, South Dakota, Wisconsin) based on total production (bushels) between 1997-2001. Three of these states-Kansas, Minnesota, and South Dakota-are among the top 10 wheat-producing states as well.

For each county in the 10 states evaluated, all cropland soil types in land capability classes (LCCs) I-VIII are identified. For each individual soil type, acres of that particular soil type, field topology characteristics (percentage low and high slopes), erodibility, and tolerable soil-loss limit are obtained from the USDA. These data are used in the rain and wind erosion equations described later. In each of the states analyzed, the following crop rotations are considered (where applicable): continuous corn, corn-soybean, corn-winter wheat, corn-spring wheat, continuous winter wheat, winter wheat-soybeans.

For each of these crop rotations, three tillage scenarios (conventional, reduced/mulch, and no-till) are considered. Conventional tillage scenarios consist mainly of moldboard plowing and/or heavy disking, reduced/ mulch tillage scenarios include light disking and chisel plowing, and the no-till scenarios use field operations that provide little or no disturbance to the field surface. Harvest, planting, tillage, and chemical application dates for each field operation are adjusted to reflect the most likely time of year and month that they are expected to occur within each of the 10 states. Tables 2 and 3 describe field operations for each crop rotation and tillage combination analyzed.

\section{Residue Production}

The quantity of residue that is produced and can potentially be removed is directly related to the production yields of crops in the rotation. County-level harvested acres, yield, and total production for 1997-2001 were obtained from USDA-NASS, and 5-yr averages were determined from these data for all counties in the 10 states. These average yields were then converted to gross residue estimates using ratios of fresh grain weight to bushel factors and ratios of dry weight residues to fresh grain weight. For the three major crops considered, these factors were as follows: for corn, $25.1 \mathrm{~kg}$ of dry stover $/ \mathrm{bu}$ of grain $(56 \mathrm{lb} / \mathrm{bu})$ and a 1-to-1 ratio of dry stover to fresh grain mass; for spring wheat, $35.4 \mathrm{~kg}$ of dry residue/bu $(60 \mathrm{lb} / \mathrm{bu})$ 
Table 2

Field Operations Associated with Corn Rotations for Conventional, Reduced/Mulch, and No-till Field-Management Practices

\begin{tabular}{|c|c|c|}
\hline $\begin{array}{l}\text { Continuous corn for grain } \\
\text { (conventional till) }\end{array}$ & $\begin{array}{l}\text { Corn for grain-soybeans } \\
\text { (conventional till) }\end{array}$ & $\begin{array}{l}\text { Corn for grain-winter wheat } \\
\text { (conventional till) }\end{array}$ \\
\hline $\begin{array}{l}\text { moldboard plow; } 8 " \mathrm{~N} \\
\text { Disk har-tand.fnsh N } \\
\text { cult; secdry-sw6-12 N } \\
\text { planter; st dbl dsk N } \\
\text { cult; row-mult sweepN } \\
\text { harvest }\end{array}$ & $\begin{array}{l}\text { moldboard plow; } 8 \text { " F } \\
\text { disk har-tand.fnsh F } \\
\text { cult; secdry-sw6-12 F } \\
\text { planter; st dbl dsk F } \\
\text { cult; row-mult sweepF } \\
\text { harvest }\end{array}$ & $\begin{array}{l}\text { moldboard plow; } 8 \text { " N } \\
\text { disk har-tand.fnsh N } \\
\text { cult; scdry-sw6-12 N } \\
\text { planter; st dbl dsk N } \\
\text { cult; row-mult sweepN } \\
\text { harvest }\end{array}$ \\
\hline & $\begin{array}{l}\text { moldboard plow; 8" F } \\
\text { disk har-tand.fnsh F } \\
\text { cult; secdry-sw6-12 F } \\
\text { planter; st dbl dsk F } \\
\text { cult;row-mult sweepF } \\
\text { harvest }\end{array}$ & $\begin{array}{l}\text { moldboard plow; 8" N } \\
\text { disk har-tand.fnsh N } \\
\text { cult; scdry-sw6-12 N } \\
\text { drill; dbl dsk opn N } \\
\text { harvest }\end{array}$ \\
\hline $\begin{array}{l}\text { Continuous corn for grain } \\
\text { (mulch till) }\end{array}$ & $\begin{array}{l}\text { Corn for grain-soybeans } \\
\text { (mulch till) }\end{array}$ & $\begin{array}{l}\text { Corn for grain-winter wheat } \\
\text { (mulch til) }\end{array}$ \\
\hline $\begin{array}{l}\text { chis-disk; str.pt. N } \\
\text { cult; secdry-sw6-12 N } \\
\text { planter; st dbl dsk N } \\
\text { harvest }\end{array}$ & $\begin{array}{l}\text { chis-disk; str.pt. F } \\
\text { cult; secdry-sw6-12 F } \\
\text { planter; st dbl dsk F } \\
\text { harvest } \\
\text { chis-disk; str.pt. N } \\
\text { cult; secdry-sw6-12 N } \\
\text { planter; st dbl dsk N } \\
\text { harvest } \\
\text { drill; dbl dsk opn N } \\
\text { harvest }\end{array}$ & $\begin{array}{l}\text { chis-disk; sweeps N } \\
\text { disk har-tand.fnsh N } \\
\text { cult; secdry-sw6-12 N } \\
\text { planter; st dbl dsk N } \\
\text { harvest } \\
\text { chis-disk; sweeps N } \\
\text { disk har-tand.fnsh N } \\
\text { cult; secdry-sw6-12 N }\end{array}$ \\
\hline $\begin{array}{l}\text { Continuous corn for grain } \\
\text { (no till) }\end{array}$ & $\begin{array}{l}\text { Corn for grain-soybeans } \\
\text { (no till) }\end{array}$ & $\begin{array}{l}\text { Corn for grain-winter wheat } \\
\text { (no-till) }\end{array}$ \\
\hline $\begin{array}{l}\text { anhydrous applic. N } \\
\text { planter; NT-fluted c N } \\
\text { harvest }\end{array}$ & $\begin{array}{l}\text { anhydrous applic; disk F } \\
\text { planter; strip-t flute F } \\
\text { harvest } \\
\text { drill; NT-f.res. ri N } \\
\text { harvest }\end{array}$ & $\begin{array}{l}\text { planter; NT-fluted c N } \\
\text { harvest } \\
\text { drill; NT-f.res. fl N } \\
\text { harvest }\end{array}$ \\
\hline
\end{tabular}

and a 1.3-to 1-ratio of dry residue (chaff and straw) to grain; and for winter wheat, $46.3 \mathrm{~kg} / \mathrm{bu}$ of grain $(60 \mathrm{lb} / \mathrm{bu})$ and a 1.7-to-1 ratio of dry residue to grain. For soybeans, these factors were $40.8 \mathrm{~kg}$ of dry residue $/ \mathrm{bu}(60 \mathrm{lb} / \mathrm{bu})$ and a 1.5-to-1 ratio of dry residue to beans (6). 
Table 3

Field Operations Associated with Wheat Rotations for Conventional, Reduced/Mulch, and No-till Field-Management Practices

\begin{tabular}{ll}
\hline Continuous wheat (conventional till) & Winter wheat-soybeans (conventional till) \\
\hline moldboard plow; 8" N & moldboard plow; 8" N \\
disk har-tand.fnsh N & disk har-tand.fnsh N \\
disk har-tand.fnsh N & cult; secdry-sw6-12 N \\
drill; dbl dsk opn N & planter; dbl dsk op N \\
harvest & cult; row-mult sweepN \\
& harvest \\
& moldboard plow; 8" N \\
& $\begin{array}{l}\text { disk har-tand.fnsh N } \\
\text { cult; secdry-sw6-12 N } \\
\text { drill; dbl dsk opn N } \\
\text { harvest }\end{array}$ \\
\hline Continuous wheat (mulch till) & Winter wheat-soybeans (mulch till) \\
\hline disk har-tand.prim N & chis-disk; sweeps N \\
drill; dbl dsk opn N & cult; secdry-sw6-12 N \\
harvest & Planter; st dbl dsk N \\
& harvest \\
& chis-disk; sweeps F \\
cult; secdry-sw6-12 F \\
drill; dbl dsk opn F \\
harvest \\
\hline Continuous wheat (no-till)
\end{tabular}

To quantify the amount of residue that can be sustainably removed, quantities of residues that must be left on the field to maintain rain and/or wind erosion at or below tolerable soil-loss levels $(T)$ must first be estimated. The revised universal soil loss equation (RUSLE) and the wind erosion equation (WEQ) are used to estimate these residue quantities $(7,8)$. 
RUSLE and WEQ are designed primarily to estimate long-term, average annual soil erosion on a site-specific field characterized by a particular soil type, slope and runoff length, field length, cropping and management practices used, and localized climate conditions. Residues that must be left on the field, with respect to rainfall and wind erosion, are estimated for each soil type, each crop rotation, and each tillage combination considered in this analysis, with the higher of the two estimates being the quantity needed to remain on the field.

\section{Rainfall Erosion (RUSLE)}

The RUSLE (Eq. 1) is used to estimate the quantities of residue that must remain on the field to keep rainfall-induced erosion at or below $T$.

$$
A=R \times K \times S \times L \times C \times P
$$

in which $A$ is the average annual soil loss (metric $\mathrm{t} /[\mathrm{ha} / \mathrm{yr}]$ ), $R$ is the rainfall-runoff erosivity factor (location/county specific), $K$ is the soil erodibility factor, $S$ is the slope steepness factor, $L$ is the slope-length factor, $C$ is the cover-management factor, and $P$ is the support-practices factor. The $A$ in RUSLE can be replaced by $T$ (tolerable soil loss limit) to give

$$
T=R \times K \times L \times S \times C \times P
$$

in which $K$ and $S$ are as described for Eq. 1 and are specific to each soil type examined. $P$ is assumed to be 1.0 , which provides the most conservative estimate for residue removal. All factors except $C$ are independent of crop grain yield or crop-management practices and can be combined into a single value termed ASTAR $\left(\mathrm{A}^{*}\right)$, which is specific to each particular soil type. ASTAR was calculated for each LCC I-VIII soil type in each of the 10 states.

$C$ is a function of the yield at harvest and is directly influenced by field operations that affect field surface cover throughout the year (i.e., tillage). To estimate the annual erosion and quantities of removable crop residues attributable to specific field operations and harvest yields, the C-factor must be determined in relation to these conditions. Equation 2 can be rewritten as

$$
C=(R \times K \times L \times S \times P) / T
$$

in which $C$ is now the only unknown parameter. To solve for $C$, the RUSLE C-Batch Program (developed by USDA National Soil Survey Center) is used. C-Batch estimates $C$-factors for various crop rotations, crop grain yield variations, and tillage operations and timing combinations. For this analysis, crop grain yields of $124,198,247,309$, and $371 \mathrm{bu} /$ ha for corn; $62,74,99,124$, and $148 \mathrm{bu} / \mathrm{ha}$ for winter wheat; and $49,62,86,111$, and 124 $\mathrm{bu} /$ ha for spring wheat are assumed. Soybean yields were 37, 62, 74, 86, and $111 \mathrm{bu} / \mathrm{ha}$. These yields reflect typical ranges for these crops in most states considered in the study.

Table 4 shows variation in the $\mathrm{C}$-factor with respect to a continuous corn and continuous winter wheat rotation for each of the three tillage 
Table 4

Variation in Cover-Management Factors for Continuous Corn and Continuous Winter Wheat Rotation for Conventional, Reduced/Mulch, and No-Till Field-Management Practices in Brown County, Kansas

\begin{tabular}{|c|c|c|c|c|c|c|c|c|c|}
\hline \multirow[b]{2}{*}{$\begin{array}{l}\text { C-factors } \\
\text { for continuous corn }\end{array}$} & \multicolumn{3}{|c|}{ Conventional till } & \multicolumn{3}{|c|}{ Reduced/mulch till } & \multicolumn{3}{|c|}{ No-till } \\
\hline & 0.455 & 0.291 & 0.203 & 0.318 & 0.167 & 0.104 & 0.148 & 0.057 & 0.027 \\
\hline Yield (bu/ha) & 124 & 247 & 371 & 124 & 247 & 371 & 124 & 247 & 371 \\
\hline $\begin{array}{l}\text { C-factors for con- } \\
\text { tinuous winter wheat }\end{array}$ & 0.206 & 0.133 & 0.092 & 0.083 & 0.039 & 0.022 & 0.042 & 0.017 & 0.008 \\
\hline Yield (bu/ha) & 62 & 99 & 148 & 62 & 99 & 148 & 62 & 99 & 148 \\
\hline
\end{tabular}

scenarios and three grain yield levels in Brown County, Kansas. The Cfactors vary between the two crops owing to different protective cover for corn stover vs wheat straw, with lower C-factors associated with greater protective cover. They also vary across the three tillage scenarios for each crop (on average, the $\mathrm{C}$-factor decreases as the tillage scenario becomes less aggressive, going from conventional till to reduced/mulch to no-till). This is logical because as residue burial increases (such as with a moldboard plow and / or heavy disking representative of conventional till), less protective cover is present on the field and, therefore, it is more likely for soil erosion to occur. From the standpoint of the RUSLE equation, erosion increases when the cover-management factor increases, because ASTAR is constant for a single soil type and erosion is the product of ASTAR and the $\mathrm{C}$-factor. In practical terms, for the same soil type and cropping rotation, more residue is potentially available for removal under no-till field management vs mulch till or conventional till field-management practices because less residue is buried and more residue stays on the field surface to protect against the impact of rainfall and wind forces.

Estimation of Minimum Retainable Residue Levels for Continuous (Single)-Crop Rotation-Rainfall Erosion

The estimated C-factors corresponding to each crop rotation, tillage, and grain yield combination are multiplied by the soil-specific ASTAR values to obtain expected erosion rates $(\mathrm{Mg} /[\mathrm{ha} \cdot \mathrm{yr}])$ for each soil type. To determine crop residue levels $(\mathrm{Mg} /[\mathrm{ha} \cdot \mathrm{yr}])$ for which expected erosion rates are at or below $T$, a regression curve is fitted to the data, with the variables of the independent variable, the natural logarithm of the residue produced (quantity of stover and/or straw present in the field at the time of harvest), and of the dependent variable, the erosion rate. The level of soil erosion varies depending on the quantities of residue left on the field at the time of harvest and throughout the year. Given that expected erosion (for each soil type, crop rotation, and tillage practice combination) is estimated for five grain crop yields ( $\mathrm{bu} / \mathrm{ha}$ ), the regression is fitted to five data pairs. 
Table 5

Calculation of Minimum Remaining Residue Levels for Rainfall-Induced Soil Erosion

\begin{tabular}{lccccc}
\hline \multicolumn{5}{c}{ (Continuous Corn, Mulch Till, Shidler-Catoosa Silt Loam, Allen County, Kansas) } \\
\hline $\begin{array}{l}\text { Corn yield } \\
\quad(\mathrm{bu} / \mathrm{ha})\end{array}$ & 124 & 198 & 247 & 309 & 371 \\
$\begin{array}{l}\text { Erosion } \\
\quad(\mathrm{Mg} /[\mathrm{ha} \cdot \mathrm{yr}])\end{array}$ & 20.79 & 15.19 & 11.70 & 9.16 & 7.68 \\
$\begin{array}{l}\text { Corn residue produced } \\
\quad(\text { dry Mg/ha) }\end{array}$ & 3.14 & 5.03 & 6.29 & 7.86 & 9.43 \\
$\begin{array}{l}\text { Natural logarithm } \\
\text { of corn residue produced }\end{array}$ & 1.145 & 1.615 & 1.839 & 2.062 & 2.244 \\
\hline
\end{tabular}

Estimated results

\begin{tabular}{cccc}
\hline $\begin{array}{c}\mathrm{T} \text {, tolerable soil loss } \\
(\mathrm{Mg} /[\mathrm{ha} \cdot \mathrm{yr}])\end{array}$ & Intercept & Slope & $\begin{array}{c}\text { Average minimum residue remaining } \\
(\text { dry } \mathrm{Mg} /[\mathrm{ha} \cdot \mathrm{yr}])\end{array}$ \\
\hline 11.2 & 34.755 & -12.269 & 6.82 \\
\hline
\end{tabular}

A natural logarithmic function provides the best fit. For a single/continuous-crop rotation (continuous corn or continuous wheat), the minimum quantities of residue $\left(R_{\min }\right)$ that must remain on the field throughout the year to keep erosion at or below $T$ are estimated by rearranging the fitted regression equation (Eq. 4). The quantities of residues that can be removed $\left(R_{\text {rem }}\right)$ are estimated as the quantity of residue produced $\left(R_{\text {prod }}\right)$ minus the minimum quantity that must remain $\left(R_{\min }\right)$ (Eq. 5). If $R_{\text {prod }}$ is less than $R_{\min }$ no residue can be removed.

$$
\begin{gathered}
R_{\min }=\exp [(T-\text { intercept }) / \text { slope }] \\
R_{\text {rem }}=R_{\text {prod }}-R_{\text {min }}
\end{gathered}
$$

Table 5 presents the regression analysis and estimated quantities of residues that must remain on the field subject to a reduced/mulch till, continuous corn rotation on a Shidler-Catoosa silt-loam soil in Allen County, Kansas. In this example, the regression equation is fitted to the following five pairs of erosion and dry residue-equivalent yield data (20.79 and 1.145, 15.19 and 1.615, 11.70 and 1.839, 9.16 and 2.062, and 7.68 and 2.244). This provides an estimated intercept of 34.755 and a slope of -12.269 . Using Eq. 5 and a $T$ value of $11.2 \mathrm{Mg} /(\mathrm{ha} \cdot \mathrm{yr}$ ), the quantity of residue that must remain on the field is estimated as $6.82 \mathrm{Mg} /$ (ha.yr).

Estimation of Minimum Retainable Residue Levels

for Multiple-Crop Rotation-Rainfall Erosion

Estimated residues that can be removed for a 2-yr, multiple-crop rotation differ from the continuous-crop, single-year analysis in that removal rates must remain at or below $T$ for each year of the rotation. 
Table 6

Variation in Cover-Management Factor for Corn-Soybean Rotation for Conventional, Reduced/Mulch, and No-Till Field-Management Practices

\begin{tabular}{lcccccccccc}
\hline & \multicolumn{3}{c}{ Conventional till } & \multicolumn{3}{c}{ Reduced/mulch till } & \multicolumn{3}{c}{ No-till } \\
\hline $\begin{array}{c}\text { Yield } \\
\text { (bu/ha) }\end{array}$ & $124 /$ & $247 /$ & $371 /$ & $124 /$ & $247 /$ & $371 /$ & $124 /$ & $247 /$ & $371 /$ \\
$\begin{array}{c}\text { Average residue } \\
\text { levels (Mg/ha) }\end{array}$ & 37 & 74 & 111 & 37 & 74 & 111 & 37 & 74 & 111 \\
$\begin{array}{c}\text { C-factors for } \\
\text { corn-soybean }\end{array}$ & 2.33 & 4.66 & 7.0 & 2.33 & 4.66 & 7.0 & 2.33 & 4.66 & 7.0 \\
\hline
\end{tabular}

The average annual residue present at harvest over the 2-yr period is calculated at each of the five yield pairs from the C-batch program (e.g., for a corn-soybean rotation, the yield pairs of 124/37, 198/62, 247/74, $309 / 87$, and $371 / 111 \mathrm{bu} / \mathrm{ha}$ equate to average residue levels of $2.33,3.78$, $4.66,5.7$, and $7.0 \mathrm{dry} \mathrm{Mg}$ / (ha.yr), respectively, over the 2 -yr period). As with continuous-crop rotations, the $\mathrm{C}$-factors vary between rotations (i.e., soybean residue provides less protective cover than corn stover, resulting in higher $\mathrm{C}$-factors for a corn-soybean rotation than a continuous-corn rotation), and across all tillage practices (i.e., the $\mathrm{C}$-factor decreases as tillage becomes less intensive). (Note that the total residue produced during the two-year rotation is twice the 2 -yr average). Table 6 illustrates how rotational C-factors vary with respect to tillage for a corn-soybean rotation in the Midwest.

For a multiple-crop rotation, residues that must remain $\left(R_{\min }\right)$ are calculated by the same equation used for a continuous-crop rotation (Eq. 4), except the intercept and slope are functions of the 2-yr average residue levels of each residue pair. $R_{\min }$ represents the amount of residue that must be left in the field each year of the rotation to ensure that rainfall erosion does not exceed $T$. Note that $R_{\min }$ is the same for both cropping years. This follows because the $\mathrm{C}$-factor was calculated on the basis of a rotation, not two independent crops. Unlike the continuous-crop rotation, however, three potential situations can arise that will affect residue quantities that can be removed.

Situation No. 1

Both crops produce more residue each year than $R_{\min }$. If the residueequivalent production yields of both crops are greater than $R_{\min }$, then the residues from each crop can be removed and are estimated according to Eqs. 6 and 7.

$$
\begin{aligned}
& A R R 1=R 1_{\text {prod }}-R_{\text {min }} \\
& A R R 2=R 2_{\text {prod }}-R_{\text {min }}
\end{aligned}
$$


in which $A R R 1$ and $A R R 2$ are the average annual removable residue from crops one and two, $R 1_{\text {prod }}$ and $R 2_{\text {prod }}$ are the gross residues produced for crops one and two (based on the average production yield of crops one and two in the county), and $R_{\min }$ is the average minimum residue over the 2-yr period.

Situation No. 2

The average residue produced by the two crops is less than $R_{\min }$. If the residue quantity produced for either crop $\left(R 1_{\text {prod }}\right.$ or $\left.R 2_{\text {prod }}\right)$ is less than the average minimum residue, $R_{\min }$, then a test is conducted to determine whether the average annual residue produced by the rotation (the sum of the gross residue produced by each crop divided by two), $A R R$, is less than $R_{\min }$. If it is, then no residue can be removed in either year. If the average is greater than $R_{\min }$ situation \#3 arises.

SituATION No. 3

The average residue produced by the two crops is greater than $R_{\min }$ but one crop, Äôs residue is less than $R_{\min }$. This situation also involves the position that one of the crops produces an amount of residue less than $R_{\text {min }}$ (the average minimum residue), but the difference between $A R R$ and $R_{\min }$ is greater than zero. In this situation, it is acceptable to remove residue from only the crop that produces more residue than $R_{\min }$ provided that enough residue from that crop is left to ensure that the average amount of residue left on the field over the $2 \mathrm{yr}$ is at least as great as $R_{\min }$. No residue can be removed from the crop that produces less residue than $R_{\min }$. Mathematically, in this situation, the amount of residue removed from the crop that produces "excess" residue is equal to twice the average annual residue $-R_{\min }$. For example, if $R_{\min }=2.2 \mathrm{Mg} /(\mathrm{ha} \cdot \mathrm{yr}), R 1_{\text {prod }}=3.36$, and $R 2_{\text {prod }}=$ $1.8 \mathrm{Mg}$ / (ha.yr), respectively, then no residue could be removed from crop two and $0.76 \mathrm{Mg} /$ (ha.yr) could be removed from crop one the year it was grown.

\section{Wind Erosion (WEQ)}

Estimation of Minimum Retainable Residue Levels

for Continuous-Crop Rotation

In general, crop residue removal was affected by wind erosion more than rainfall erosion in the western two-thirds of Kansas, Nebraska, and South Dakota. Rainfall erosion was the dominant erosive force in the eastern one-third of these three states, as well as all the other seven states considered. Equation 8 presents WEQ:

$$
E=f(W I, W K, W C, W L, W V)
$$

in which $E$ is the average annual soil loss ( $\mathrm{Mg} /[\mathrm{ha} \cdot \mathrm{yr}])$; WI is the wind erodibility index (a measure of soil susceptibility to detach and be transported by wind) and varies by individual soil type; WK is the soil ridge-roughness factor and describes the condition of the field surface at a particular time; 
$W C$ is the climate factor and represents the amount of erosive wind energy present at a particular (county-level) location; $W L$ is a function of wind direction, field length, and width and is the unsheltered median travel distance of wind across a field; and $W V$ is the vegetative factor. The relationship between $E$ and the other variables is highly nonlinear.

The amount of residue potentially available for removal with respect to applying WEQ was determined by analyzing total soil loss attributable to wind forces in each field-management period (time between each field operation) for all individual soil types and then summing across all fieldmanagement periods including crop growth. These values were then compared to erosion values obtained in the rainfall erosion analysis, and the greater required minimum residue level at harvest was chosen. A detailed discussion of the application of WEQ to agricultural crop residue removal is provided in an article by Nelson (9).

\section{Results}

Tables 7 and 8 present data concerning maximum quantities of corn stover and wheat residue, respectively, that could potentially be removed from agricultural cropland in each of the 10 largest corn-producing states in the United States subject to the constraints of the tillage scenarios, production yields, soil types, and field topologies considered in this analysis. The removable residue quantities presented in this article reflect removable residue with respect to only soil erosion and no accounting/methodology was performed with respect to the impact removing residue would have on, e.g., soil tilth and nutrients. These are amounts that could be removed if all agricultural cropland (not just those in corn, wheat, and soybeans) in each state were planted to a particular rotation and subject to conventional, reduced/mulch, and no-till field-management practices (tillage scenarios), and the counties achieved crop yields equivalent to the 1997-2001 5-yr average. The quantities are the lesser of the two quantities that can be removed under the rain and wind erosion analyses.

For example, if all agricultural cropland in Iowa were managed in a continuous-corn, no-till rotation, 84.4 million dry $\mathrm{Mg}$ of corn stover could be harvested annually. If all the agricultural cropland were managed in a corn-winter wheat rotation using mulch till practices, 30.2 million dry $\mathrm{Mg}$ of corn stover and 13.4 million dry $\mathrm{Mg}$ of wheat residue could be harvested annually. (Note, that if a county did not produce a specific crop during 1997-2001, then it is assumed that crop is not produced in that county and thus any rotation with that crop is also not produced in that county; the same constraint is not applied regarding to tillage practices.) An assumption was made that all tillage practices are possible in all counties.

In addition, it should be noted that not all estimated residue quantities will actually be removed owing to the potential of some farmers being unwilling to remove residues from their fields, as well as weather conditions that may prohibit collection. Other factors may come into play as well. 


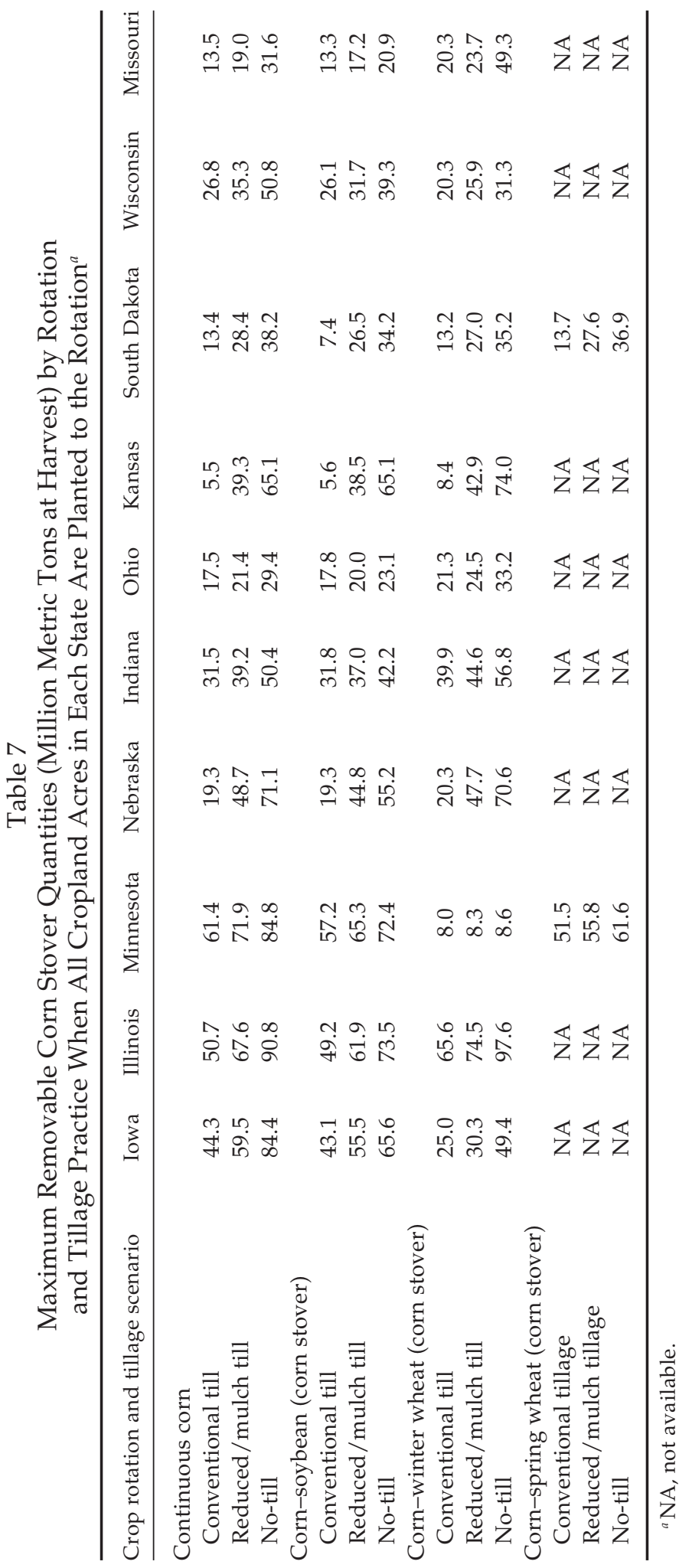




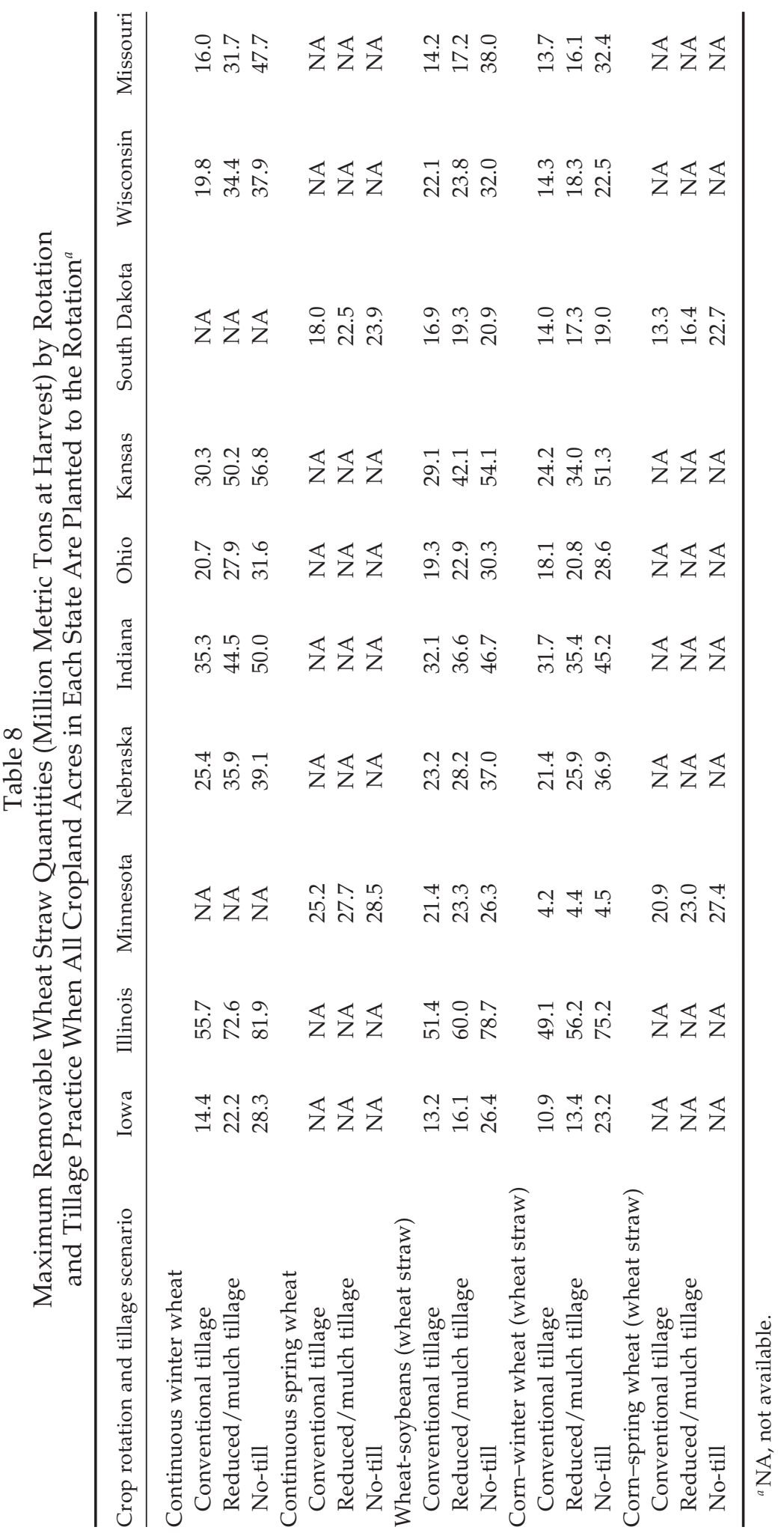


Quantities can be adjusted for these factors by assuming that only a certain percentage of the estimated quantities is actually removed.

The estimated quantities of removable corn stover and wheat straw presented in Tables 7 and 8 conform to intuitive expectations in that as tillage operations become less intensive (i.e., go from conventional to no-till), the amounts of removable residue increase across all rotations in all states. Differences in estimated removable quantities among states is a function of several factors including production location (whether the majority of production occurs in areas that have highly erodible soils and field topology nonconducive to removal), climatic/erosive conditions at the locations of production, and actual yields at these specific locations among others. These factors must be considered before residues can be removed at any specific location.

\section{Conclusion}

A methodology was developed to assess the amount of agricultural crop residue that can be removed without exceeding the tolerable soil-loss limit in both single and multicrop (2-yr) rotations. Application of this methodology to select corn- and wheat-based cropping rotations on land capability class I-VIII soils subject to conventional, reduced/mulch, and no-till field-management practices in Iowa, Illinois, Nebraska, Minnesota, Indiana, Ohio, Kansas, South Dakota, Missouri, and Wisconsin indicates that significant removable quantities of corn stover and wheat straw exist, but there is considerable variation in the amounts of removable residue with respect to each tillage scenario across all states analyzed. These amounts only consider the need to keep erosion to a tolerable level and do not encompass soil carbon considerations.

\section{References}

1. Energy Information Administration. (2003), in Annual Energy Outlook 2003 with Projections to 2025, US Department of Energy, Washington, DC, p. 18.

2. Energy Information Administration. (2003), Annual Energy Outlook 2003 with Projections to 2025, US Department of Energy, Washington, DC.

3. Energy Information Administration. (2003), in Annual Energy Outlook 2003 with Projections to 2025, U S Department of Energy, Washington, DC, p. 4.

4. Energy Information Administration. (2003), in Annual Energy Outlook 2003 with Projections to 2025, US Department of Energy, Washington, DC, p. 3.

5. Nelson, R. G., Enersol Resources. (2001), Resource Assessment, Removal Analysis, Edgeof-Field Cost Analysis, and Supply Curves for Corn Stover and Wheat Straw in the Eastern and Midwestern United States, National Renewable Energy Laboratory, Golden, CO.

6. Larson et al. (1979), in Journal of Soil and Water Conservation, Special Publication No. 25, Soil Conservation Society of America, Ankeny, IA.

7. US Department of Agriculture. (1997), Predicting Soil Erosion by Water: A Guide to Conservation Planning with the Revised Universal Soil Loss Equation (RUSLE), Agricultural Handbook Number 703, US Department of Agriculture, Agricultural Research Service.

8. Skidmore, E. L. (1988), in Soil Erosion Research Methods, Soil and Water Conservation Society of America, Ankeny, IA.

9. Nelson, R. G. (2002), Biomass Bioenergy 22, 349-363. 